\title{
The Notion of "Device" in Giorgio Agamben
}

\author{
Rubén Dittus \\ School of Communications, Central University of Chile, Santiago, Santiago Metropolitan Region, Chile \\ Email: ruben.dittus@ucentral.cl
}

How to cite this paper: Dittus, R. (2019) The Notion of "Device" in Giorgio Agamben. Advances in Applied Sociology, 9, 47-59. https://doi.org/10.4236/aasoci.2019.91004

Received: October 1, 2018

Accepted: January 5, 2019

Published: January 8, 2019

Copyright $\odot 2019$ by author(s) and Scientific Research Publishing Inc. This work is licensed under the Creative Commons Attribution-NonCommercial International License (CC BY-NC 4.0). http://creativecommons.org/licenses/by-nc/4.0/

\begin{abstract}
The device was one of the most revolutionary concepts formulated by Michel Foucault for the study of ideologies and systems of thought. Despite this, it was not defined by the French philosopher. Recently, a refreshing of the idea has been developed by the Italian Giorgio Agamben, for whom the notion of device is associated with the political space and the legal system of the governed, where models of control and pollution models remind us that we were once something different from what we are today. This article presents the notion of a device as everything that facilitates the recognition of the human, using, for this, subjectivity. It is the image of the subject in the car, in the bar, in the school, in the economy, in politics, etc., those that delineate and legitimize the constitutive features of a subject that feeds from itself. The subject is reflected in the device, and it guides and defines it.
\end{abstract}

\section{Keywords}

Device, Foucault, Agamben, Power, Politics, Anthropological Machine

\section{Introduction}

The "device" is a poorly defined term, which makes it a challenging job and an opportunity to enter unknown fields. In the bibliographic review carried out to delimit its references, ambiguity and diversity of applications were observed according to the epistemic plot that uses it. Dictionaries link the "device" with that "mechanism arranged to obtain a result" or the "artifact, machine or device that serves to do something". The common language, on the other hand, associates it with an artifice, subsisting the idea of apparatus or ordering according to an end. Thus, for example, one speaks of the "telephone device" or the "police device". The idea of the agency is the one that has more relation with the concept, pointing to a control or domination. It is for this reason that great prominence has had in sociology of science, whose purpose is to deepen the analysis of the production, circulation and reception of scientific/technical knowledge. 
The device operates, then, as a mechanism or a network of relationships that unites, orients or controls according to an objective. The field of philosophy has been approached by thinkers such as Michel Foucault, Gilles Deleuze or Jean-Francois Lyotard, and refers to the set of rules, institutions, categories and forms of control that exist between human beings and their social practices. Therefore, we can understand the device as a network of imaginary relationships that discipline social existence to configure an order. In one of his few definitions of the term, Foucault (1984) says in an interview granted in 1977:

"What I try to indicate with this name is, in the first place, a resolutely heterogeneous group that includes speeches, institutions, architectural installations, regulatory decisions, laws, administrative measures, scientific statements, philosophical, moral, philanthropic propositions, said, as well as what is not said, these are the elements of the device. The device itself is the network that is established between these elements" (Foucault, 1977b: p. 299).

This is the interview entitled "Le jeu de Michel Foucault" in which, for the first time, and explicitly defines one of the concepts most associated with his philosophy. The term as such-device-appears published as part of the work of Foucault only from "Watch and punish" (1976) and disappears completely in the last two volumes of the "History of sexuality" (1977a), having abundant employment in "History of Sexuality I". That is, it was not until 1977 that the French philosopher outlines the term, and only because it is interrogated by the interviewer. It is a valuable paragraph, since it definitely guides conceptual understanding and definitively separates it from ideas of epistemè or discourse. There, when asked about the meaning and the methodological function of the term, he affirms that the device is like a heterogeneous set and acts as a network that connects these different elements. Those elements of the network are not fixed, they can change their positions, their functions. These functions have the purpose-at a given historical moment-of responding to an emergency. "The device has a dominant strategic function" that can only be understood in its specific situation and does not respond to any forecast of "a meta or trans historic subject that would have perceived or wanted it", explains the interviewee (Foucault, 1977b: p. 300).

Beyond the abysses or conceptual approaches, there is consensus in placing the notion of device as part of the deep reflection carried out by the philosophy of Michel Foucault (1976b, 1977b). We are not oblivious to this observation. However, the thesis of the device in Michel Foucault is controverted from beginning to end. Not only because it accumulates relationships more than epistemic limits, but because of the core of its thinking rests in its particular way of understanding power (Foucault, 1970; 1973). And it does so by recognizing the historical status of scarcely questioned fields, such as scientific activity. Contrary to the prevailing positivism, both in natural and social sciences, his position on the ineffectiveness of the classic cause-effect relationship when dealing with historical processes led him to identify a new status of what is considered naturally instituted. Official history is not the product of a rational will that manifests it- 
self in concrete facts, but is more a random juxtaposition of events, where irrationality dominates more than coherence. The order and progress of history would be nothing more than an illusion constructed by historians and of which we need, because we do not want, in any way, to realize this. History is knowledge, it will be the maxim (Foucault, 1980; 1984; 1992). And after its formulation, sooner or later an epistemological cataclysm would be unleashed.

Recently, it was the Italian Giorgio Agamben who most strongly referred to the concept of a device. It extends to anything that has the ability to guide, capture, define, model or control and, thus, ensure behaviors and opinions. In this way, not only the prison, the school or the hospital would be devices, but also the pen, the writing, the computer or the means of communication. It can be conceived, even, as an act of thought, insofar as it automatically designs an angle in the understanding of the signifying environment. The device, then, has an elastic meaning and worthy of a relevant conceptual stretch in other areas and fields.

The explicit approach made by Giorgio Agamben to the thesis of Foucault's device is announced at the conference entitled "What is a device"? (Agamben, 2007) that the philosopher presented in his brief passage through Argentina, in an auditorium packed with professors and university students. The title also represented many academic texts and articles that have been written to address the notion. It is curious that many of them start with the same question. Therefore, the question was not provocative, nor less accidental. Simple and straightforward, the title he put on his conference was, in addition, the opportunity to update an old concept, coined decades before by Michel Foucault. The answer, however, was not easy. And is that the french thinker was never commissioned to define it in his writings. To alleviate titanic task, Agamben, part of a finding: philosophers do not always define the technical terms they use, just as Plato never did with an idea, the most important of its concepts. The same thing happened to Foucault with the word device, a decisive term in his thought.

In a first detailed approach to the concept, Agamben addresses as the second difficulty, the ambiguity of its meaning. And it is that Foucault not only does not define it, but refers to it in different ways to explain the passages of his theory. Sometimes it is used as a general concept to refer to what is said and not said in a society, and in other cases it is used as a specific term, to refer to institutions, architectural facilities, legal norms, discourses, administrative measures, scientific statements, provisions morals, artifacts and, most novel of the term, to refer to non-discursive practices. The device would be, for Foucault that set of provisions that condition the subject in their ways of thinking and being, that series of praxis and knowledge that define our regimes of subjectivity, such as gender or sexuality. In this way, the device is somewhat broader than the epistemè, since it refers to only discursive devices. The device would have, in Foucauldian reading, a dominant strategic function, always inscribed in a game of power.

What are the binding theoretical elements that bring us closer to the notion of device in Foucault interpreted by Giorgio Agamben? What intellectual debates 
have been held to enhance or torpedo the concept? Is it possible to elaborate a single definition of the term from the rereading of Foucault that fits the terms in which biopolitics is understood? To what extent the contribution of concepts such as "oikonomia" or "homo sacer" are applicable to other areas of studies on ideology? These are some of the questions that will guide the content of this article.

\section{Agamben and the Definition of Device}

What Agamben's thesis seeks is to emphasize that, beyond the novel utility given by the humanities to the notion of device, all of them have linked two areas of association, on the one hand, living beings or substances and, on the other, the mechanisms in which they are captured. And that dichotomy that Agamben tries to break, introducing a third element, the subjects; result of the relationship between living beings and the devices that govern them. Thus, for Agamben, there is no device without a state of subjectivation of each of the control and regulation processes associated with the concept. The user of cell phones or the Internet would be an example of this new relationship described, and with which the idea of a device linked to the construction of personal and collective identities is further enhanced. The explicitness of Agamben in this matter is not ambiguous:

"I will literally call a device anything that has in some way the ability to capture, guide, determine, intercept, model, control and ensure the gestures, behaviors, opinions and discourses of living beings. Not only, therefore, the prisons, asylums, the panopticon, the schools, the confession, the factories, the disciplines, the legal measures, etc., whose connection with the power is in a certain evident sense, but also the pen, writing, literature, philosophy, agriculture, smoking, navigation, computers, cell phones and-why not-the language itself, which is perhaps the oldest of the devices, in which thousands and thousands of years a primate-probably without realizing the consequences that would follow-had the unconsciousness of being captured' (Agamben, 2008: p. 38-39).

This definition is more than timely, especially at times when the word remains elastic and/or politically incorrect. The dictionaries continue linking it to a "mechanism, device, machine or device that serves to do something". For its part, in Foucaultian terminology the term is reduced to three areas of influence. First, as an ontological device, responsible for delineating the world and its possibilities of interpretation and existence of the true; second, as a standardization and control device, whose task is to discipline behavior and punish any form of deviation and abnormality; third, as a surveillance device, so that the proposed social order is maintained according to the parameters of the legally and morally accepted. The legacy of Foucault designates the device as that set of moral and legal norms, scientific paradigms, institutions of government and administration, ontological categories and forms of control that exist between human beings and their social practices. It is that network of imaginary relationships that discipline social existence to configure an order. From this point of view, the de- 
vice is born with the subject, and has evolved with it, assuming various forms and regimes of control, along with the evolutionary pair of knowledge, religion and technology. A device is a social regime producing subjects tied to regulatory mechanisms that have different ways of control, regulation and surveillance, historically located and invisible to the uninstructed human eye.

The device is for Agamben a non-accidental concept to understand the processes of change that have altered the natural life of a substance that, after an ontological separation, is now placed on the label of homo sapiens. This "hominization" process that has made "humans" to animals-is nothing more than the result of models of control and contamination, which reminds us that we were once something different, but only in part. Thus, homo sapiens would not be a substance or a clearly defined species, but rather a machine or an artifice to produce the recognition of the human. For Agamben, this label is the result of an anthropogenic or anthropological device, a kind of optical machine constituted by a series of mirrors in which man sees his own image deformed with monkey features, similar to man. By opposition, the anthropological device-anthropogenesis-assures hominization to the species, through the identification of the non-man.

The device reminds homo-and its entire evolutionary chain up to homo sapiens sapiens - that has a double nature, celestial and earthly, that is located between the animal and the human, and that is a substantial part of a long road towards hominization through language. The discussion on this point deserves special attention. Agamben postulates that it is precisely the disagreement over the origin of the linguistic monkey that complicates the anthropological machine, given that it is a historical fact, rather than a physiological one. Because if there existed in evolution a talking ape-a homo alalus-you cannot say with certainty that this animal did not have a germ of humanity. If this hypothesis is accepted, the figure of a man-animal would be true. But the mono-man label is not ruled out, after the humanization of the animal. That is, the prelinguistic state guarantees the evolutionary duality of the animal-man and the animal-man.

From the moment in which the determinant of the human is the opposition between the human and the inhuman, the anthropological device works through inclusion and exclusion. It does not seem strange, then, that for the Agambenian perspective that simian-man binomial applies to later centuries in the categories of barbarian, Jew, slave or foreigner, or what is the same, "figures of an animal with human form". In this thesis, this arises, the naked life, a zone of indifference and articulation between the human and the animal. It is the extreme figure of the human and the inhuman that will lead Agamben to speak of the open as an ontological status of the animal environment. "Openness without revelation"-he writes (Agamben, 2005b: p. 72) — that defines the poverty of the animal, in its stunning in the disinhibiting circle of the non-human. Contemporary devices have taken care that this continues to be the case. The capture of the human through biological labels and subjectification constitute the insurmoun- 
table marks of oikonomia.

What is the link that Agamben proposes between oikonomia and the philosophy of the devices? The root of the matter has a theological heritage, because the current Christian theology articulates and divides, at the same time, in God, the being and the praxis; the nature or essence and the way in which he administers and governs the world of creatures. In this difference, the term device refers to an oikonomia, and serves to denominate that set of praxis, of knowledge, of measures, of institutions, whose objective is to administer, govern, control and orient, in a sense that is supposed to be useful, the behaviors, gestures and thoughts of men (Agamben, 2008: p. 37). That is to say, the device that Foucault speaks of-for Agamben-is linked to the act of government that does not intervene in the essence of the creatures, but in arranging the ways to carry out a good government.

This difference, however, did not always exist. Oikonomia means in Greek "the administration of the house, the material management of the home". Agamben explains the need for the Church to introduce this term as part of the theological nomenclature. That's where the Trinity has something to say. During the second century, and after a strong tension within the Church between those who defended the coexistence of three divine figures (Father, Son and Spirit) and those who considered them an incentive for the emergence of polytheism and paganism in the Christian faith, Oikonomia is established as a way of defending the production of the essence, in charge of God, and the management of the history of men in Christ, without letting this divine figure be present in this home and earthly economy. Its application will be of enormous relevance for monarchies, in which there was no separation of functions between politics, economics and theology; all of them dimensions of a single government.

"Thus, the term oikonomia means, in particular, the incarnation of the Son and the economy of redemption and salvation (that is why, in some agnostic sectors, Christ is going to be called the man of the economy). Theologians, little by little, will end up distinguishing between a discourse-a logos-of theology and a logos of economics. And the oikonomia is developed as a device through which the dogma of the trinity and the idea of a divine providential government of the world are introduced into the Christian faith" (Agamben, 2008: p. 35).

According to the author, as a result of the theologians trying to avoid and remove God from the plane of being, schizophrenia in the theological doctrine would not be long in coming. After the theological break, it reappears in the form of a censorship that separates being and action, ontology and praxis. With this, both politics and economics rest in oikonomy, acting as a device in the management plane, but which has no basis in the essence of creatures. The oikonomía happens, thus, to be control, norm and orientation to reach the eternal salvation of the humanity, but from the action, the praxis.

\section{The Birth of Biopolitics}

The inheritance that remained for the western culture shows a theology that 
surpasses the threshold of the individual conscience and imposes itself in each public activity. This reasoning allows Agamben to be one step beyond Foucault's device. To the two great groups or classes that the French philosopher recognizes-the substances or living beings and the devices that govern those beings-Agamben introduces a third category: the subjects. "I call the subject what results from the relationship or, so to speak, from body to body between the living and the apparatuses," he says. The substances and the subjects do not overlap completely, because the same individual (the same substance) can be the place of multiple processes of subjectivation, as a cell phone user, as a navigator on the Internet or as a story writer. Therefore, devices always involve processes of subjectivation. There are no subjects without the modeling of which they are subject by the devices. It is the subjectification that creates the subject.

In the current capitalist scenario, technology and globalization are the allies of what Agamben calls the proliferation of processes of subjectivation. "This may give the impression that the category of subjectivity, in our time, vacillates and loses consistency, but it is, to be precise, not a cancellation or an overcoming, but a dissemination that increases the aspect of masquerade that always accompanied to all personal identity", sentence (Agamben, 2008: p. 40). It is the confirmation of the Foucauldian biopolitics, but in a new phase, in which after the crossing of certain thresholds in the exercise of the manipulation of the bodies, the use of more sophisticated techniques has been given way. According to the thesis of Foucault in the Will of knowledge, and then in the courses that would be published posthumously, the process through which natural life begins to be included in the mechanisms and calculations of politics and power of the State is transformed into bio-politics. In this way, the old Aristotelian notion and of great validity in all these centuries is surpassed, and according to which the human being in his condition of political subject, leaves aside his animal nature or, at least, his life as a living being is put into question (Foucault, 1977a: p. 173). With the birth of biopolitics, Foucault will transform into a paradigm of contemporary philosophy the idea that the species and the individual, as a simple living body, becomes the objective of the political strategies of the Polis.

Biological life, individual security and the health of the population are now subjects of sovereign power, which has given way to a State of the population, a government of men. According to Agamben, the death of Foucault prevented the development of biopolitics and its effects, as he understood it. Anyway, it indicates, "the politicization of naked life as such, constitutes the decisive event of modernity, which marks a radical transformation of the political-philosophical categories of classical thought" (Agamben, 1998: p. 13). What is at stake is the legitimation of a model of citizenship where free and democratic participation in the affairs of the Polis is not extended, but where bureaucratic authority guarantees security through the signing of the most private element of subjectivity: life biological of the bodies. It is, therefore, technological devices that reduce the old public space by means of the inscription and classification of a life converted in- 
to a body; a naked life without politics; a sacred life but not an animal, the naked life.

In effect, the "naked life" is a central concept in the philosophy of Giorgio Agamben and arises as a corollary of the notion of bio-politics, coined by Foucault. The natural life of men comes to occupy, in the very heart of world capitalism, the center of the Polis. Now it is the turn of naked life, opposed to the term life-form that incorporates a political and public dimension, never isolated. Before biopolitics, human behaviors and ways of living were not conditioned by a specific biological need, but by a universal theological vocation, where happiness was at stake, which "immediately constitutes the life-form as political life" (Agamben, 2001: p. 14). It is a conception far removed from the sovereign power spoken of by Hobbes in The Leviathan, and where life in the state of nature is defined only by the fact of being exposed to a threat of death. Political life gives the sovereign the power to decide about life or death, always protected in the category of political life. Gone is the stage of legal-institutional power.

How do the two most emblematic forms of power of Foucault's thought converge in Agamben's work? Is there a point of connection between the legal-institutional model and the biopolitical model of power? For the Italian philosopher, the Foucauldian thesis must be "corrected or, at least, completed", because it leaves loose ends to reach this confluence of powers. He adds: "what characterizes modern politics is not the inclusion of zoe (life) in the polis (...) what is decisive is, rather, the fact that, parallel to the process by virtue of which the exception is As a rule, the space of bare life that was originally located outside the juridical order, coincides progressively with the political space, so that (...) right and fact enter an area of irreducible undifferentiation" (Agamben, 1998: p. 19). It is an anthropogenic device that was not differentiated by Foucault. It is the exclusion from the difference between the legal and the animal. It is the sacred life, the naked life.

\section{Homo Sacer}

This anthropogenesis updates an archaic figure of Roman law: the homo sacer, whom anyone could kill and have no punishment for it. It is a form of impunity that arises with the existence of a subject that was considered divine domain. Sacer is a Latin expression meaning "that is in the power of the gods and their worship," which is why it cannot be sacrificed. Homo sacer, then, was that sacred subject. Its origin, however, predates the distinction between profane and sacred, between religious and legal, becoming a case of legal ambiguity. Agamben devotes a large part of his intellectual career to researching homo sacer, a legal label he uses as a form of exclusion in contemporary societies, and which inspires the nomination of two of his works: "Homo Sacer I: Sovereign power and naked life" (1998) and "Homo Sacer II: The Kingdom and the Glory" (2008).

In the framework of this tracking, it establishes a connection between the 
Latin sacer and the figure of the taboo, subjects associated with impure facts and, therefore, temporarily isolated from the community: infected, post-partum women, men who had been in contact with corpses, etc. The fear of natural pain or contagion justifies the taboo. In the anthropological and ethnographic studies published at the beginning of the 19th century, the homo sacer label has a double meaning, it is holy and cursed at the same time, an ambivalence that is contemporary with the finding of the first biblical studies carried out in the West. It is a duality that will bring consequences, located in the sacer in Roman law as an entity that is outside of human jurisdiction, but does not contradict the divine law. Thus, he belonged to the realm of the non-sacrifiable, but at the same time his life can be taken away by someone, who was not punished. It is the cost of the sacred life to be "life insatiable and to which, however, can be killed" (Agamben, 1998: p. 108).

For Agamben, it is a case of legal exception, and acts as a precedent for similar cases in the exercises of the sovereign power of the history of the West. The political space of sovereignty would have constituted an area of indifference between sacrifice and homicide. In that way, a sphere is sovereign in which one can kill without committing murder and without celebrating a sacrifice, not contravening the sphere of the sacred. At present, the homo sacer label is observed in the one with respect to which all men act as sovereigns (Agamben, 1998: p. 110). It is not a political bios, nor a natural zoe; it means, simply, a life that can be lawfully killed. Here arises the greater applicability of the Agambenian thesis: from homo sacer, the figure of the state of exception is the hidden foundation on which rests the entire political system. In that, naked life is excluded and imprisoned in the legal order, constituting, moreover, as part of their separation. The homo sacer in all its splendor.

The concentration camps during the German Nazism or the historical persecution of the gypsies in different parts of Europe are a sample of that. How are these historical aberrations understood? For Agamben, the same vindication of the naked life leads, in the bourgeois democracies, to prioritize the private over the public and the individual liberties over the collective obligations. In the case of totalitarian states, it becomes a decisive political criterion and a privileged subject of sovereign decisions, but overcoming the limits of the state of exception. These are incomprehensible intrusions of biological-scientific principles in the political order, such as the criteria of death (the principles of eugenics) or conditions before birth (induced abortion or birth control). In this perspective, the concentration camp is presented as a sample of which a pure, absolute and, until now, unsurpassed biopolitical space is possible. Other emblematic cases in Agamben's analyzes are birth and refugee status, the homeland. The birth-the naked natural life-becomes an immediate carrier of sovereignty, but also of a potential exclusion. Hence the consequences are known. An unborn in North American territory does not have the mark of that nation, and therefore neither its history, nor its customs, nor its benefits as a citizen. A biological fact marks a political life irrevocably. Refugee status, which breaks the trinity 
State-nation-territory, is marginal, but central to the political history of the West. It is the terrestitoriality, a fact of natural life associated with birth that determines it.

The anthropological device spoken of by Agamben continues to produce humanitas and imposes itself on the once historical destiny of the peoples, transformed today into "cultural spectacles and private experiences" (Agamben, 2005: p. 99). Meanwhile, the sovereign power of Hobbes, looks stunned the installation of other powerful, and how they have lost control and influence criteria of political identity such as language, blood or territory. After the biologization of life, the medical-scientific devices make use of controls and orientations with political purposes, through disciplinary readings on the body, health, illness or death. Medicalization, abortion or fear are used as a-territorial forms of survival, in a kind of new commitment to totalitarianism. The domain is, now, global. The sentence of the philosopher does not invite optimism precisely:

"It is probable that the time in which we live has not come out of this aporia. Do we not see around us and among us men and peoples without essence and without identity-consigned, so to speak, to their idleness-groping everywhere for an inheritance and a task, an inheritance as a task? Even the pure and simple renunciation of all historical tasks (reduced to simple functions of internal or international police) in the name of the triumph of the economy, today often has such intensity that the same natural life and well-being seem to be presented as the last historical task of humanity, if we admit that here it makes sense to talk about a task”(Agamben, 2005: p. 98).

A struggle with the devices, however, is not an easy task. Agamben is cautious in this matter and does not suggest a "no quarter" fight. No crashes or deactivation attempts. Otherwise, we would have no way of doing it. Any political strategy in that sense would further confirm the order we wish to destroy. On the contrary, he is in favor of taking advantage of the advantages that the figure of oikonomia gives us. His proposal consists of altering the bases of subjectivation of a government device, leaving it reduced to a mere exercise of violence. Desecration is the alternative. The desecration as against device. Profanar is used by Agamben (2008: p. 43) -following the jurist Trebacio-as that action to restore the free use and property of men, something that is sacred, holy or religious. If one considers the current meaning given to the action of the government of men, desecration would act as a counter-device that would restore something that sacrifice has divided and separated from common use. This, because sacrifice is understood as the consecration of something that was in the realm of the profane to the sacred.

Consistent with this line of thought, Agamben himself was the protagonist of a controversy that caught the attention of the media in Europe and the United States. In March 2004, the philosopher was preparing to travel as a visiting professor at the University of New York, however, after the approval of the new control measures put in place for those foreigners with visas who wished to enter that country, he expressed his intention not to travel. In an article published in 
the newspaper Le Monde on January 11 of the same year explains the reasons for this decision. "No biopolitical tattoo" is the title of the text in which Agamben categorically states not to be willing to submit to the new mandatory signing and the stamping of their fingerprints.

The cancellation of his university course-explains-has nothing to do with the sympathy and appreciation that links him for years to his colleagues and American students. Nor is it, the article continues, an epidermal reaction to a procedure that was imposed for a long time on criminals and political defendants. "The essential is not there. The problem exceeds the limits of personal sensitivity and concerns the legal-political status (it would perhaps be simpler to say bio-political) of the citizens of the supposedly democratic states in which we live "(Agamben, 2004). The case is a good example of how the Western device operates, under a logic of acceptance of control practices that had always been considered exceptional and inhumane. These are manifestations outside any democratic limit in which the use of surveillance exercised by the State far exceeds those massive electronic devices, such as credit cards or mobile phones, which have already been questioned.

It is the metaphor of the West as a concentration camp, because "the tattoo appeared in Auschwitz as the most normal and economic way to organize the registration and registration of deportees." Now, the biopolitical tattoo is the one imposed by the United States, promoting, in passing, the thesis of the end of the city, where the body was associated with politics, where the way of life was imposed on biology.

"The electronic capture of fingerprints and retina, subcutaneous tattoo, like other practices of the same gender, is elements that help define that threshold. The security reasons that are invoked to justify them should not impress us: that is not the issue. History teaches us that the practices reserved at the beginning of foreigners, immediately apply to all citizens. (...) Thus, when applying to the citizen or rather to the human being as such, the techniques and devices that were invented for the dangerous classes, the States, which should constitute the very place of political life, have made it the human being, the suspect par excellence, to the point that it is humanity itself that has transformed into a dangerous class" (Agamben, 2004).

In the Agambenian thesis, the capitalist-democratic project seeks to suppress the split that divides the people, radically terminating the existence of such exclusionary forms, but incorporating other inclusion techniques. It is about-says (Agamben, 2001: p. 34)—of the attempt carried out by capitalist and socialist countries, of right and left, to generate a single people, unique and undivided. It is the reason why the overcoming of oikonomia is, in the words of Agamben, more than urgent, especially in a society where the sovereign power aspires to an ellipsis of politics where the great processes of de-targeting do not resemble or correspond with real subjectivations, but where they follow experiences previously applied in totalitarian regimes. It is the obsession with development and progress that would justify the application of a biopolitical project that seeks to 
produce a people without symbolic or imaginary fractures. The homologation between political life and naked life. It is the providential government of the world that, sheltered in the task of salvation, would be leading us to catastrophe. Agamben invites us to reflect on the scope of a device that surpasses Foucault's initial studies on power, and to understand the features of an anthropological machine that combines the production of naked life as an original political element and as a threshold of articulation between nature and culture.

\section{Final Words}

The philosophical contribution of Agamben describes the possible worlds as realities molded from the control and surveillance of devices that guarantee a proper normalization of attitudes and behaviors; past and future; realities and fictions. It is through the devices where the human being learns to leave behind his animal behavior as a species, a rupture that places him as a privileged entity of an anthropological machine that accommodates the vagaries of biopolitics, and updates its conditions for an ethical life, with rights and duties. Gone is the wild animal terrain. Today is a new version of the talking monkey-homo sapiens sapiens-which has been allowed to capture. As Agamben explains, only in the government of men does life make sense. In it, the guilty pleasures of a man accustomed to rendering an account to an authority that has no face or place and that watches over every corner of consciousness, but without being seen, are submitted.

Does the theoretical contribution of Agamben facilitate the conceptual applicability of the device in other areas and subjects? The agambenian oikonomia translates unequivocally the results of the first studies of Michel Foucault. There all this complex and decentralized set of knowledge, practices, media and institutions converge, whose objective is to manage, control and guide the behaviors, gestures and thoughts of people, in a sense of apparent usefulness and conservation. Hence, not only are jail, sexuality, psychiatric hospital, school or army devices. So are the sports club, literature, philosophy, mobile telephony, Internet, television, theater and cinema. All of them are, and each of the symbolic gears that constitute them form a network of power, protocols and influences on knowledge. If the device is everything that facilitates the recognition of the human, then every device is, by scope, an anthropological device, which is constituted from the mirrors that the human being uses to reflect his subjectivity. It is the image of the subject in the car, in the bar, in the school, in the economy, in politics, etc., those that delineate and legitimize the constitutive features of a subject that feeds from itself. The subject is reflected in the device, and it guides and defines it.

The capture of the human is exercised today by new anthropological machines, whose marks of identity and subjectivity are insurmountable. There is no subject without devices, and these have adapted to the new demands of the modern world. 


\section{Conflicts of Interest}

The author declares no conflicts of interest regarding the publication of this paper.

\section{References}

Agamben, G. (1998). Homo sacer. El poder soberano y la nuda vida [Homo Sacer. The Sovereign Power and the Naked Life]. Valencia: Pre-textos.

Agamben, G. (2001). Medios sin fin. Notas sobre la politica [Endless Means. Notes on the Policy]. Valencia: Pre-textos.

Agamben, G. (2005). Lo abierto. El hombre y el animal [The Open. The Man and the Animal]. Valencia: Pre-textos.

Agamben, G. (2007). Qu'est-ce qu'un dispositif? [What Is a Device?]. Paris: Éditions Payot \& Rivages.

Agamben, G. (2008). El reino y la gloria. Homo sacer II [The Kingdom and the Glory. Homo Sacer II]. Buenos Aires: Adriana Hidalgo.

Foucault, M. (1970). Arqueología del saber [Archeology of Power]. México: Siglo XXI.

Foucault, M. (1973). El orden del discurso [The Order of the Speech]. Barcelona: Tusquets.

Foucault, M. (1976). Vigilar y castigar. Nacimiento de la prisión [ Watch out and Punish. Birth of the Prison]. Buenos Aires: Siglo XXI.

Foucault, M. (1977a). Historia de la sexualidad (Vol. 1) [History of Sexuality (Vol. 1)]. México: Siglo XXI.

Foucault, M. (1977b) El juego de Michel Foucault (Interview). Ornicar, 62-93, and Michel Foucault, Dits et écrits II, Quarto-Gallimard, París, 2001.

Foucault, M. (1984). El juego de Michel Foucault. En Saber y verdad [The Game of Michel Foucault. In Knowledge and Truth]. Madrid: La Piqueta. 